\title{
Antigen levels of urokinase-type plasminogen activator receptor and its gene polymorphism related to microvessel density in colorectal cancer
}

\author{
Karolina Przybylowska1 ${ }^{1 凶}$, Janusz Szemraj ${ }^{2}$, Andrzej Kulig ${ }^{3}$, Adam Dziki ${ }^{4}$, \\ Joanna Ulanska ${ }^{5}$ and Janusz Blasiak ${ }^{1}$ \\ ${ }^{1}$ Department of Molecular Genetics, University of Lodz, Eódź, Poland; ${ }^{2}$ Department of Medical Biochemistry, \\ Medical University in Lodz, Lodz, Poland; ${ }^{3}$ Polish Mother's Memorial Hospital - Research Institute, Łódź, Po- \\ land; ${ }^{4}$ Department of General and Colorectal Surgery, Medical University of Lodz, Eódź, Poland; \\ ${ }^{5} 2^{\text {nd }}$ Department of Surgery, Medical University of Lodz, Łódź, Poland
}

Received: 24 April, 2007; revised: 14 April, 2008; accepted: 30 April, 2008

available on-line: 29 May, 2008

\begin{abstract}
We determined the distribution of genotypes and frequencies of alleles of the (CA) repeat polymorphism in intron 3 of the urokinase plasminogen activator receptor (uPAR) gene, uPAR antigen levels and microvessel density (MVD) in tumour and distant mucosa samples from 52 patients with colorectal cancer. The uPAR level was higher for patients with high MVD comparing to patients with lower MVD which may suggest that UPAR can be correlated with progression of colorectal cancer. The significant relationship between the high MVD and uPAR antigen level appeared to be independent of the $(C A)_{n}$ repeat polymorphism because no differences in the level of UPAR antigen between carriers of alleles were found. The received results, indicate that UPAR might be considered as a target in colorectal cancer patients' therapy.
\end{abstract}

Keywords: plasminogen activation system, urokinase type plasminogen activator receptor (uPAR), gene polymorphism, colorectal cancer, cancer progression, angiogenesis, microvessel density

\section{INTRODUCTION}

The vascularization in human colorectal tumour has been reported to be a significant predictor of an increased risk of haematogenous metastatic disease (Shpitz et al., 2003; Pang \& Poon, 2006; Rajaganeshan et al., 2007). The increase in tumour vessel density raises the chance for cancer cells to enter the circulation (Sieczkiewicz et al., 2002). Newly formed vessels or capillaries have leaky and weak basement membranes that can be penetrated by cancer cells more easily than those of mature vessels (Nagy et al., 1998). Additionally, escape of tumour cells into the tumour neovasculature is facilitated by the degradative enzymes secreted by the endothelial cells on the tips of growing capillar- ies, and recent data suggest that the urokinase plasminogen activator (uPA) system and matrix metalloproteinases (MMP) are essential for this process (Baker \& Leaper, 2003; Kim et al., 2006). The urokinase plasminogen activator receptor (uPAR) is anchored on the cell-surface membrane and specifically recognizes pro- and active uPA (Nielsen et al., 1988). The binding of uPA to uPAR strongly enhances uPA-mediated plasminogen activation and localizes the proteolytic activities on the cell surface (Reuning et al., 1997). The receptor-bound uPA catalyses the formation of plasmin on the cell surface to generate the proteolytic cascade that contributes to the breakdown of basement membranes and extracellular matrix (Ploug et al., 1993; Pepper, 2001). In many types of cancer one can observe increased

$\square$ Corresponding author: Karolina Przybylowska, Department of General and Colorectal Surgery, Medical University of Lodz, pl. Hallera 1, 90-647 Łódź, Poland; tel. (48) 42639 3075; fax (48) 42639 3075; e-mail: tonina1@wp.pl

Abbreviations: ECM, extracellular matrix; MMP, matrix metalloproteinases; MVD, microvessel density: PAI-1, plasminogen activator inhibitor type-1; PBS, phosphate-buffered saline; uPA, urokinase-type plasminogen activator; uPAR, urokinase-type plasminogen activator receptor; VEGF, vascular endothelial growth factor. 
levels of uPA, uPAR and PAI-1 in tumour in comparison to normal tissue. Therefore these factors might have an impact on the cancer development (Błasiak et al., 2000; Przybyłowska et al., 2001; 2002; Seetoo et al., 2003). Because of the essential role of uPA system components in tumour invasion and angiogenesis, it is important to determine if alterations in $u P A, u P A R$ and $P A I-1$ genes may influence on cancer development and progression. We have recently observed significantly higher levels of uPA antigens in colon cancer samples with the genotype $\mathrm{C} / \mathrm{C}$ of the $\mathrm{C} / \mathrm{T}$ polymorphism in exon 6 of the $u P A$ gene (Przybyłowska et al., 2001) These results suggest that this polymorphism might not be associated with the occurrence of cancer, but the higher level of uPA in tumour samples with the C/C genotype indicates that the $\mathrm{C}$ allele may be involved in the development and/or progression of this disease (Przybyłowska et al., 2001; 2002). The 4G/5G polymorphism of the PAI-1 gene has been associated with increased plasma levels of PAI-1 and has been linked with coronary heart disease and/or myocardial infarction (Hamsten et al., 1987; Eriksson et al., 1995). Our previous study implies that $4 G / 5 G$ and $1334 \mathrm{G} / \mathrm{A}$ polymorphism is not directly involved in the development of colorectal and breast cancer (Smolarz et al., 2003; Błasiak \& Smolarz, 2003). Increased levels of UPAR in tumour and serum are associated with worse prognosis for patients with colon cancer. This may be linked with enhanced tumour angiogenesis dependent on the uPA system (Seetoo et al., 2003). Due to the significance of uPAR production in cancer, it is important to check whether it can be affected by genetic variability. Four polymorphisms of the $U P A R$ gene have been described: a $(C A)_{n}$ repeat in intron 3, two restriction fragment length PstI and one EcoRI polymorphisms (Borglum et al., 1991; 1992; Kohonen-Corish et al., 1996). This study was designed to investigate the relationship between the level of uPAR, MVD and frequency of alleles of the $(C A)_{n}$ repeat polymorphism in colon cancer.

\section{PATIENTS AND METHODS}

Patients. Tumour tissues and distant mucosa samples were obtained from 52 patients with colorectal cancer treated at the 2nd Department of Surgery, Military Academy of Medicine, Łódź, Poland since 2000. There were 34 males and 18 females and their median age was 69 years (quartiles: 52, 74 years). All patients had histologically-confirmed advanced adenocarcinoma. Pathologic staging was obtained by grading according to WHO classification: G1 ( $\mathrm{n}=16), \mathrm{G} 2(\mathrm{n}=27), \mathrm{G} 3(\mathrm{n}=9)$; and the Dukes' criteria: A $(\mathrm{n}=12), B(\mathrm{n}=23), C(\mathrm{n}=11)$ and $\mathrm{D}$ $(n=6)$. Control samples consisted of DNA extracted from blood collected from sex and age matched 60 individuals without cancer.

Determination of the $u P A R$ genotype. DNA from tumour tissue, distant mucosa and blood samples was isolated by proteinase $\mathrm{K}$ digestion and phenol/chloroform extraction. The genotype was determined by short tandem repeat PCR (STR$\mathrm{PCR})$, using primers of flanking region that contains $(C A)_{n}$ repeat in intron 3 of the $u P A R$ gene. PCR was carried out in an MJ Research, INC thermal cycler, model PTC-100 (Waltham, MA, USA), in a total volume of $25 \mu \mathrm{l}$, containing $50 \mathrm{ng}$ genomic DNA, 10 pmol each primer: (GT strand) 5' CTT ACA TGA TGC TGG GAA CAC $3^{\prime}$ and ${ }^{32}$ P-labelled (CA strand) 5' TGG TGA TGG ATG GGT CTG TC 3' (Eurogentec, Seraing, Belgium), $200 \mu \mathrm{M}$ each dATP, dCTP, dGTP and dTTP, $20 \mathrm{mM}$ Tris/ $\mathrm{HCl}$, (pH 8.4), $50 \mathrm{mM} \mathrm{KCl}, 2 \mathrm{mM} \mathrm{MgCl}_{2}$, and 1 unit Taq polymerase (Qiagen $\mathrm{GmbH}$, Hilden, Germany) (Kohonen-Corish et al., 1996). The thermal cycling conditions were: $3 \mathrm{~min}$ at $94^{\circ} \mathrm{C}$, followed by 35 cycles of $30 \mathrm{~s}$ at $95^{\circ} \mathrm{C}, 1 \mathrm{~min}$ at $60^{\circ} \mathrm{C}$ and $1 \mathrm{~min}$ at $72^{\circ} \mathrm{C}$. To determine allele size the PCR products were subjected to electrophoresis in $6 \%$ polyacrylamid formamide sequencing gels. Gels were then dried and exposed to X-ray film (Fig. 1).

The uPAR antigen levels. Samples of tumour tissue and distant mucosa of $50 \mathrm{mg}$ wet mass were pulverised at $4^{\circ} \mathrm{C}$ in TBS buffer $(20 \mathrm{mM}$ Tris/ $\mathrm{HCl} \mathrm{pH}$ 8.5, $125 \mathrm{mM} \mathrm{NaCl}_{2}, 1 \%$ Triton $\left.\mathrm{X}-100\right)$. The suspension was ultracentrifuged $(105000 \times g)$ at $4^{\circ} \mathrm{C}$ for 45 min and the resulting cytosol fractions were collected and immediately used. uPAR antigen level was quantified by sandwich enzyme linked immunosorbent assay (ELISA) using commercially available IMBIND Total uPAR ELISA kit (American Diagnostica Inc., Greenwich, CO, USA). Absorbance was measured at $450 \mathrm{~nm}$ and the antigen levels in $\mathrm{ng} / \mathrm{ml}$ were obtained from standard curves. The UPAR antigen content was expressed as nanograms of analysed

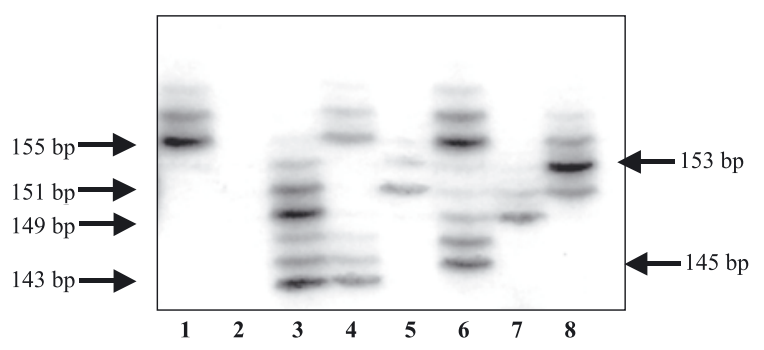

Figure 1. Autoradiogram of SRT-PCR products containing fragments of intron 3 of $U P A R$ gene with highly polymorphic $(C A)_{n}$ region analysed by $6 \%$ polyacrylamid formamide sequencing gel electrophoresis.

Lanes display bands for: 1 - 155bp/155bp, 3 - 149/143, 4 - 155bp/143bp, 5 - 151bp/151bp, 6 - 155bp/145bp, 7 149bp/149bp, $8-153 / \mathrm{bp} 153 \mathrm{bp}$. 
per milligram of tissue protein. Protein was assayed by the Bradford method (Bradford, 1976).

Microvessel staining and evaluation. All tissue samples of primary colorectal cancer were fixed in $10 \%$ buffered formalin and routinely processed for light microscopy. Sections (4-mm thick) were dewaxed in xylene and dehydrated in ethanol. The sections were predigested with protease for $20 \mathrm{~min}$ at $37^{\circ} \mathrm{C}$ and then immersed in $3 \% \mathrm{H}_{2} \mathrm{O}_{2}$ for $30 \mathrm{~min}$ to inhibit endogenous peroxidase. After washing with PBS, they were incubated in normal rabbit serum for $30 \mathrm{~min}$, followed by incubation overnight with anti-factor VIII polyclonal antibody (DAKO, Corp.) at a $1: 50$ dilution. The sections were then incubated with biotinylated rabbit antimouse IgG for $15 \mathrm{~min}$. Peroxidase-conjugated with streptavidin was used at a dilution of $1: 200$. After washing in PBS, the slides were developed by immersing into $0.01 \% \quad \mathrm{H}_{2} \mathrm{O}_{2}$ and $0.05 \%$ diaminobenzidine tetrahydrochloride for 2 min. Normal mouse IgG was substituted for the primary antibody in the negative control. The sections were counterstained with hematoxylin. After staining, blood vessels appeared intensely brown in colour, which facilitated identification and quantification.

Microvessels within the tumour were counted in immunohistochemically stained sections under light microscopy as an indicator of tumour angiogenesis (factor VIII) (Kumar et al., 1998). After screening the areas with intense neovascularization at low magnification $(\times 40$ or $\times 100)$, microvessels were counted in a $\times 200$ field. In all samples, the mean value of microvessel number was calculated from four different fields (Fig. 2).

Statistical analysis. The observed numbers of genotypes were compared with those expected for a population in Hardy-Weinberg equilibrium using the $\chi^{2}$ test. The significance of the observed al-

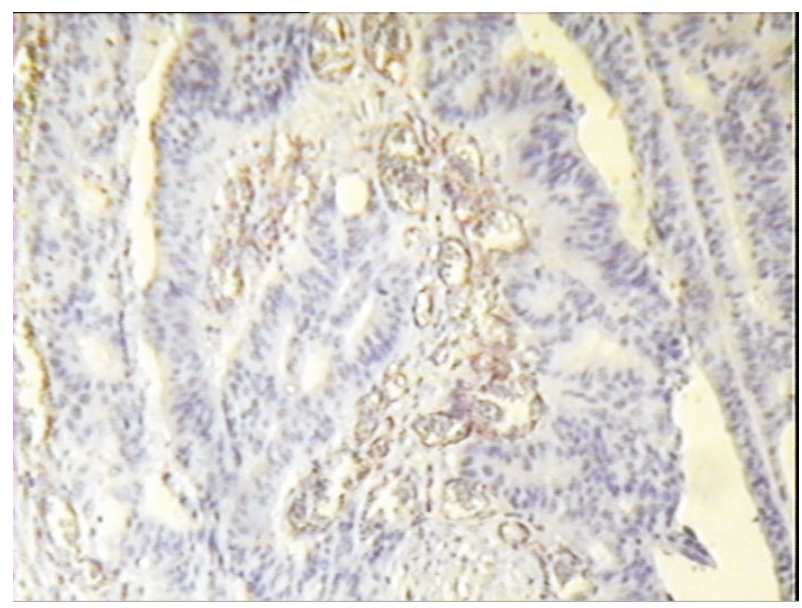

Figure 2. Immunohistochemical staining for factor VIII of primary colorectal carcinoma.

Microvessels are represented by brown capillaries or clusters.
Table 1. Clinicopathologic parameters and microvessel density of colorectal cancer samples

\begin{tabular}{lr}
\hline Microvessel count per field (mean \pm S.D. $)$ \\
\hline Total & $94.13 \pm 34.19$ \\
Sex & \\
Male & $93.76 \pm 31.41$ \\
Female & $91.18 \pm 24.85$ \\
& \\
Grading (WHO) & \\
G1 & $95.75 \pm 29.41$ \\
G2 & $88.57 \pm 31.12$ \\
G3 & $102.61 \pm 40.51$ \\
Dukes' stage & \\
A & $90.57 \pm 34.78$ \\
B & $96.33 \pm 24.04$ \\
C/D & $118.31 \pm 31.51$ \\
\hline
\end{tabular}

leles and genotype differences between groups was tested using $\chi^{2}$ analyses. To determine normal distribution, the Shapiro-Wilk test was used. Student's $t$-test (for normal distribution) or Mann-Whitney test (for non-normal distribution) was used to compare each parameter between two groups. An ANOVA test was first used to identify parameters that would cause significant differences between more than two groups; Scheffe's test was then used to investigate the significance of difference in each identified parameter between any two groups. Analyses were performed using STATISTICA 6.0 (Statsoft, Tulsa, OK, USA).

\section{RESULTS}

Table 1 shows the clinicopathologic parameters and MVD of colorectal cancer samples. No differences $(P>0.05)$ in the MVD of colorectal cancer samples between tumour variables were observed.

Table 2. The $(C A)_{n}$ repeat polymorphism in intron 3 of the $u P A R$ gene. Frequencies of alleles by patients with colorectal cancer and in blood samples of controls

\begin{tabular}{|c|c|c|c|}
\hline \multirow{2}{*}{$\begin{array}{l}\text { Allele } \\
(\mathrm{CA})_{\mathrm{n}} \text { repeat }\end{array}$} & \multicolumn{3}{|c|}{ Frequency of alleles } \\
\hline & $\begin{array}{l}\text { Colorectal can } \\
(\mathrm{n}=52)\end{array}$ & $\mathrm{r}$ patients & $\begin{array}{l}\text { Controls } \\
(\mathrm{n}=60)\end{array}$ \\
\hline $\begin{array}{l}\text { Length } \\
\text { (bp) }\end{array}$ & Tumour tissue & $\begin{array}{l}\text { Distant } \\
\text { mucosa }\end{array}$ & Blood \\
\hline 139 & 0.016 & 0.016 & 0.033 \\
\hline 141 & 0.081 & 0.081 & 0 \\
\hline 143 & 0.016 & 0.016 & 0.050 \\
\hline 145 & 0.032 & 0.032 & 0.033 \\
\hline 147 & 0.452 & 0.452 & 0.483 \\
\hline 149 & 0.161 & 0.161 & 0.183 \\
\hline 151 & 0.112 & 0.112 & 0.133 \\
\hline 153 & 0.016 & 0.016 & 0 \\
\hline 155 & 0.048 & 0.048 & 0.050 \\
\hline 159 & 0.045 & 0.045 & 0.033 \\
\hline
\end{tabular}


Table 3. The $(\mathrm{CA})_{\mathrm{n}}$ repeat polymorphism in intron 3 of the $u P A R$ gene.

Frequencies of alleles by patients with colorectal cancer and tumour variables.

\begin{tabular}{|c|c|c|c|c|c|}
\hline \multirow{2}{*}{$\begin{array}{l}\text { Allele } \\
(\mathrm{CA})_{\mathrm{n}} \text { repeat }\end{array}$} & \multicolumn{5}{|c|}{ Frequency of alleles } \\
\hline & Grading & & Dukes' stag & & \\
\hline Length (bp) & G1 $(n=16)$ & G2/ G3 $(n=36)$ & $\mathrm{A}(\mathrm{n}=12)$ & $B(n=23)$ & $\mathrm{C} / \mathrm{D}(\mathrm{n}=17)$ \\
\hline 139 & 0 & 0.022 & 0 & 0 & 0.05 \\
\hline 141 & 0.05 & 0.087 & 0.125 & 0.076 & 0.05 \\
\hline 143 & 0 & 0.022 & 0.062 & 0 & 0 \\
\hline 145 & 0 & 0.043 & 0 & 0.076 & 0 \\
\hline 147 & 0.7 & 0.304 & 0.375 & 0.269 & 0.6 \\
\hline 149 & 0.1 & 0.195 & 0.25 & 0.153 & 0.15 \\
\hline 151 & 0.1 & 0.131 & 0 & 0.269 & 0.05 \\
\hline 153 & 0.5 & 0.022 & 0 & 0.076 & 0 \\
\hline 155 & 0 & 0.065 & 0.125 & 0.038 & 0 \\
\hline 159 & 0 & 0.065 & 0.062 & 0.038 & 0.05 \\
\hline
\end{tabular}

Table 4. Average uPAR antigen levels in tumour tissue and distant mucosa samples in patients with colorectal cancer

\begin{tabular}{|c|c|c|}
\hline Allele $(\mathrm{CA})_{\mathrm{n}}$ repea & Distant mucosa & Tumour tissue \\
\hline Length (bp) & \multicolumn{2}{|c|}{ Antigen uPAR levels (ng/mg protein) } \\
\hline & Median (quartiles) & Median (quartiles) \\
\hline 139 & $0.239(-;-)$ & $0.283(-;-)$ \\
\hline 141 & $2.143(-;-)$ & $3.266(-;-)$ \\
\hline 145 & $0.172(-;-)$ & $1.118(-;-)$ \\
\hline 147 & $1.018(0.235 ; 2.227)$ & $0.734(0.390 ; 3.755)$ \\
\hline 149 & $1.792(0.235 ; 3.127)$ & $3.447(0.696 ; 4.881)$ \\
\hline 151 & $1.334(0.736 ; 1.792)$ & $2.835(0.364 ; 4.881)$ \\
\hline 155 & $1.173(-;-)$ & $2.212(-;-)$ \\
\hline 157 & $2.454(-;-)$ & $2.355(-;-)$ \\
\hline 159 & $1.985(-;-)$ & $3.092(-;-)$ \\
\hline total & $1.792(0.234 ; 2.455)$ & $2.356(0.617 ; 4.208)$ \\
\hline
\end{tabular}

${ }^{*} P<0.05$ as compared with distant mucosa samples.

Ten alleles of $(C A)_{n}$ repeat polymorphism in intron 3 of the $U P A R$ gene were detected in the control and the patients. Table 2 shows the $(C A)_{n}$ repeat polymorphism frequencies of alleles in tumour tissue and distant mucosa samples from colorectal cancer patients and blood samples from controls. Both kinds of samples from each patient had the same genotype. There were no differences $(P>0.05)$ between the frequencies of alleles in patients and controls, but two alleles (141 bp, $153 \mathrm{bp}$ ) were detected only in patients. A distinct preference of heterozygotes $(67 \%$ - patients, $64 \%$ - controls) was observed. Table 3 shows the frequencies of alleles of $(C A)_{n}$ repeat polymorphism in intron 3 of the $u P A R$ gene by patients and tumour variables. There were no differences $(P>0.05)$ between the distributions of the genotypes in these groups.

The results of the uPAR antigen level measurements in tumour tissues and distant mucosa samples are presented in Table 4. The uPAR antigen level was compared for different groups of homozygotic and heterozygotic patients depending on allele
Table 5. Average uPAR antigen level in tumour tissue and distant mucosa samples in patients with colorectal cancer and tumour variables

\begin{tabular}{lll}
\hline Average uPAR level (ng/mg protein) & \\
\hline & $\begin{array}{l}\text { Distant mucosa } \\
\text { sample } \\
\text { Median (quartiles) }\end{array}$ & $\begin{array}{l}\text { Tumour tissue } \\
\text { sample } \\
\text { Median (quartiles) }\end{array}$ \\
\hline $\begin{array}{l}\text { Grading (WHO) } \\
\text { G1 }\end{array}$ & $1.79(0.95 ; 2.14)$ & $3.27(0.62 ; 4.88)$ \\
G2 & $1.03(0.23 ; 2.45)$ & $1.46(0.73 ; 3.09)$ \\
G3 & $1.27(0.57 ; 1.89)$ & $2.41(0.30 ; 4.52)$ \\
Dukes' stage & & \\
A & $2.26(0.21 ; 3.13)$ & $2.35(0.39 ; 3.45)$ \\
B & $0.87(0.23 ; 2.14)$ & $1.14(0.69 ; 3.27)$ \\
C/D & $1.73(0.65 ; 2.05)$ & $2.43(0.31 ; 4.32)$ \\
\hline
\end{tabular}

present. A significant $(P<0.05)$ increase of the uPAR antigen level in tumour tissue samples was observed as compared with distant mucosa. No differences in the level of uPAR antigen between the alleles of the $(\mathrm{CA})_{\mathrm{n}}$ repeat polymorphism was found. Table 5 shows relationships between the median levels of uPAR antigen in tumour tissues with tumour characteristics. No differences $(P>0.05)$ in the level of UPAR antigen between tumour variables were detected.

Table 6 shows relationships between allele frequencies and the median levels of UPAR antigen and microvessel density. The level of uPAR antigen in tumour samples with $126.92 \pm 27.48$ microvessels per field was significantly $(P<0.05)$ higher then the level in samples with $54.14 \pm 5.01$ or $83.83 \pm 9.95$ microvessels per field. Additionally, no differences in the MVD between the alleles of the $(C A)_{n}$ repeat polymorphisms were found.

\section{DISCUSSION}

In intratumoural angiogenesis, one of the first mechanisms activated during cancer cell inva- 
Table 6. Frequencies of alleles and average UPAR antigen level in tumour tissue and distant mucosa samples of patients with colorectal cancer and microvessel density

\begin{tabular}{|c|c|c|c|}
\hline \multicolumn{4}{|c|}{ Microvessel count per field (mean \pm S.D.) } \\
\hline & Low MVD & Medium MVD & High MVD \\
\hline Alleles & 0-60 per $\times 200$ field & $60-100$ per $\times 200$ field & $>100$ per $\times 200$ field \\
\hline$(\mathrm{CA})_{n}$ repeat & $(5414 \pm 501)$ & $(8383 \pm 995)$ & $(12692 \pm 2748)$ \\
\hline Length (bp) & Frequency of alleles & & \\
\hline 139 & 0.036 & 0 & 0 \\
\hline 141 & 0.142 & 0 & 0.083 \\
\hline 143 & 0.036 & 0 & 0 \\
\hline 145 & 0.036 & 0 & 0.083 \\
\hline 147 & 0.250 & 0.545 & 0.583 \\
\hline 149 & 0.320 & 0.136 & 0 \\
\hline 151 & 0.071 & 0.227 & 0.083 \\
\hline 153 & 0.036 & 0 & 0 \\
\hline 155 & 0.071 & 0.045 & 0 \\
\hline 159 & 0.036 & 0.045 & 0 \\
\hline \multicolumn{4}{|c|}{ Antigen uPAR levels (ng/mg protein) } \\
\hline & Median (quartiles) & Median (quartiles) & Median (quartiles) \\
\hline Tumour tissue & $0.736(0.212 ; 0.870)$ & $1.115(0.364 ; 3.209)$ & $3.357(1.774 ; 4.882)^{*}$ \\
\hline Distant mucosa & $0.734(0.390 ; 1.463)$ & $1.029(0.283 ; 2.745)$ & $2.131(1.792 ; 2.387)$ \\
\hline
\end{tabular}

${ }^{*} P<0.05$ as compared with $0-60$ and $60-100$ microvessel count samples.

sion and metastasis is peritumour proteolysis. The two predominant proteinase systems involved in ECM proteolysis are the plasminogen activators and matrix metalloproteinases which act in the pericellular environment through a series of interacting activation cascades regulated by specific inhibitors. uPA specifically generates plasmin, which has been shown to initiate the autoactivation of many MMPs (Pepper, 2001; Gillette et al., 2003). The hypothesis of an uPA system role in angiogenesis is supported by two observations: neovascularization inhibition by an antagonist of uPA and a correlation between microvessel density and uPA levels in cancer (Hildenbrand et al., 1995; Min et al., 1996). Recently, it has been reported that endostatin inhibits angiogenesis through down-regulation of the PA system in a colorectal cancer cell line (Reijerkerk et al., 2003; Dkhissi et al., 2003). Thus, the inhibition of uPA and/or uPAR activity may inhibit not only tumour invasion, but also angiogenesis in colorectal cancer, and uPA and/or UPAR can be used as a marker of colorectal cancer biological behaviour.

In the present work a significantly higher level of UPAR antigen was observed in samples with high microvessel density ( $>100$ per field) than in samples with low (<60 per field) or medium density (60-100 per field). Additionally, we found the level of uPAR antigen in tumour samples to be higher than the level in distant mucosa samples. These results confirm earlier observations on increased level of UPAR in colorectal cancer and an association between the UPA system and angiogenesis. VEGF has been shown to cause up-regulation of uPA and UPAR in endothelial cells (Mandriota et al., 1995). Moreover, a previous study demonstrated that the PA system and VEGF synergistically contributed to liver metastasis of colorectal cancer (Baker et al., 2000; Konno et al., 2001).

VEGF promotes proliferation of endothelial cells and tube formation after degradation of the ECM by the PA system and/or MMPs (Zheng et al., 2006; Kong et al., 2007). Interestingly, stepwise analysis demonstrated that uPA mRNA, uPAR mRNA and VEGF protein expression were significantly correlated with MVD. The UPA, UPAR and VEGF produced by colon cancer cells destroy ECM, which may promote migration of both cancer cells and endothelial cells. On the other hand, cancer cells with high invasive ability may have various malignant potentials, including VEGF production. Since we found a positive correlation between high MVD and higher level of UPAR antigen, it is possible that the PA system enhances VEGF-induced tumor angio- 
genesis, which is in agreement with a study in gastric cancer (Kaneko et al., 2003).

Transcriptional regulation of the $U P A R$ gene is important in the control of the malignant behaviour of colon cancer cells (Wang et al., 1994). It is not known yet whether the $(\mathrm{CA})_{\mathrm{n}}$ repeat polymorphism of the UPAR gene may have an effect on the regulation of the UPAR gene expression. This polymorphism occurs in intron 3, and it might be involved in some events in nuclear splicing. We found here no differences in the level of UPAR antigens in groups with different alleles in intron 3 . These results confirm the assumption that this site polymorphism is probably phenotypically silent. However, in previous study three alleles (127 bp, $141 \mathrm{bp}, 145$ bp) were specific to colon cancer cell lines (Kohonen-Corish et al., 1996). We found eight alleles 139 bp, 143 bp, 145 bp, 147 bp, 149 bp, 151 bp, 155 bp, $159 \mathrm{bp}$ in both: patients and control groups. There were no significant differences in the frequencies of alleles between cancer patients and control, but two alleles $141 \mathrm{bp}$ and $153 \mathrm{bp}$ with frequencies 0.081 and 0.032 , respectively, were unique to the colon cancer patients group. These results indicate that the $(C A)_{n}$ repeat polymorphism in intron 3 may not be associated with occurrence of colorectal cancer.

The association of the increased level of uPAR antigen with high microvessel density suggests that uPAR can be correlated with progression of colorectal cancer, but further study, on a larger population, should be performed to verify this hypothesis.

\section{Acknowledgement}

This work was supported by the State Committee for Scientific Research (KBN, Poland) grant number 4 P05B 01317 and University of Lodz grant number 505/450.

\section{REFERENCE}

Baker EA, Bergin FG, Leaper DJ (2000) Plasminogen activator system, vascular endothelial growth factor, and colorectal cancer progression. Mol Pathol 53: 307-312.

Baker EA, Leaper DJ (2003) The plasminogen activator and matrix metalloproteinase systems in colorectal cancer: relationship to tumour pathology. Eur J Cancer 39: 981988.

Błasiak J, Smolarz B (2003) Plasminogen activator inhibitor-1 (PAI-1) gene 4G/5G promoter polymorphism is not associated with breast cancer. Acta Biochim Polon 47: 191-109.

Błasiak J, Smolarz B, Romanowicz-Makowska H, Pertyński T (2000): Plasminogen activator inhibitor-1 (PAI-1) promoter $4 \mathrm{G} / 5 \mathrm{G}$ genotype in postmenopausal women with breast cancer. Pol J Gyneacol Invest 2: 149-154.

Borglum AD, Byskov A, Cubellis MV, Kruse TA (1991) An EcoRI polymorphism for the PLAUR gene. Nucleic Acids Res 19: 6661.
Borglum AD, Byskov A, Roldan AL, Kruse TA (1992) Two PstI polymorphisms for the urokinase-type plasminogen activator receptor gene (PLAUR). Hum Genet 89: 584.

Bradford MM (1976) A rapid and sensitive method for the quantitation of microgram quantities of protein utilizing the principle of protein-day binding. Anal Biochem 72: $248-256$.

Dkhissi F, Lu H, Soria C, Opolon P, Griscelli F, Liu H, Khattar P, Mishal Z, Perricaudet M, Li H (2003) Endostatin exhibits a direct antitumor effect in addition to its antiangiogenic activity in colon cancer cells. Hum Gene Ther 14: 997-1008.

Eriksson P, Kallin B, van't Hooft F, Bavenholm P, Hamsten A (1995) Allele-specific increase in basal transcription of the plasminogen-activator inhibitor 1 gene is associated with myocardial infraction. Proc Natl Acad Sci USA 92: 1851-1855.

Gillette KM, Forbes K, Sehgal I (2003) Detection of matrix metalloproteinases (MMP), tissue inhibitor of metalloproteinase-2, urokinase and plasminogen activator inhibitor-1 within matrigel and growth factor-reduced matrigel basement membrane. Tumori 89: 421-425.

Hamsten A, de Faire U, Walldius G, Dahlen G, Syamosi A, Landou C, Blomback M, Wiman B (1987) Plasminogen activator inhibitor in plasma: risk factor for recurrent myocardial infarction. Lancet 2: 3-9.

Hildenbrand R, Dilger I, Horlin A, Stutte HJ (1995) Urokinase plasminogen activator induces angiogenesis and tumor vessel invasion in breast cancer. Pathol Res Pract 191: 403-409.

Kaneko T, Konno H, Baba M, Tanaka T, Nakamura S (2003) Urokinase-type plasminogen activator expression correlates with tumor angiogenesis and poor outcome in gastric cancer. Cancer Sci 94: 43-49

Kim TD, Song KS, Li G, Choi H, Park HD, Lim K, Hwang BD, Yoon WH (2006) Activity and expression of urokinase-type plasminogen activator and matrix metalloproteinases in human colorectal cancer. BMC Cancer 6: 211.

Kohonen-Corish MR, Wang Y, Doe WF (1996) A highly polymorphic (CA)n repeat in intron 3 of the human urokinase receptor gene (PLAUR). Hum Genet 97: 124125.

Kong D, Li Y, Wang Z, Banerjee S, Sarkar FH (2007) Inhibition of angiogenesis and invasion by 3,3'-diindolylmethane is mediated by the nuclear factor-kappaB downstream target genes MMP-9 and uPA that regulated bioavailability of vascular endothelial growth factor in prostate cancer. Cancer Res 67: 3310-3319.

Konno H, Abe J, Kaneko T, Baba M, Shoji A, Sunayama K, Kamiya K, Tanaka T, Suzuki S, Nakamura S, Urano $\mathrm{T}$ (2001) Urokinase receptor and vascular endothelial growth factor are synergistically associated with the liver metastasis of colorectal cancer. Jpn J Cancer Res 92: 516-523.

Kumar R, Kuniyasu H, Bucana CD, Wilson MR, Fidler IJ (1998) Spatial and temporal expression of angiogenic molecules during tumor growth and progression. Oncol Res 10: 301-311.

Mandriota SJ, Seghezzi G, Vassalli JD, Ferrara N, Wasi S, Mazzieri R, Mignatti P, Pepper MS (1995) Vascular endothelial growth factor increases urokinase receptor expression in vascular endothelial cells. J Biol Chem. 270: 9709-9716.

Min HY, Doyle LV, Vitt CR, Zandonella CL, StrattonThomas JR, Shuman MA, Rosenberg S (1996) Urokinase receptor antagonists inhibit angiogenesis and pri- 
mary tumor growth in syngeneic mice. Cancer Res 56: 2428-2433.

Nagy JA, Brown LF, Senger DR, Lanir N, Van de Water L, Dvorak AM, Dvorak HF (1989) Pathogenesis of tumor stroma generation: a critical role for leaky blood vessels and fibrin deposition. Biochim Biophys Acta 948: 305-326.

Nielsen LS, Kellerman GM, Behrendt N, Picone R, Dano K, Blasi F (1988) A 55,000-60,000 Mr receptor protein for urokinase-type plasminogen activator. Identification in human tumor cell lines and partial purification. J Biol Chem 263: 2358-2363.

Pang RW, Poon RT (2006) Clinical implications of angiogenesis in cancers. Vasc Health Risk Manag 2: 97-108.

Pepper MS (2001) Role of the matrix metalloproteinases and plasminogen activator-plasmin systems in angiogenesis. Arterioscler Tromb Vasc Biol 21: 1104-1117.

Ploug M, Kjalke M, Ronne E, Weidle U, Hoyer-Hansen G, Dano K (1993) Localisation of the disulfide bond in the $\mathrm{NH}_{2}$-terminal domain of the cellular receptor for human urokinase-type plasminogen activator: a domain structure belonging to a novel superfamily of glycolipid-anchored membrane proteins. J Biol Chem 268: 17539-17546.

Przybyłowska K, Smolarczyk K, Błasiak J, Kulig A, Romanowicz-Makowska H, Dziki A, Ulańska J, Pander B (2001) A C/T polymorphism in the urokinase-type plasminogen activator gene in colorectal cancer. J Exp Clin Cancer Res 20: 569-572.

Przybylowska K, Smolarczyk K, Kulig A, RomanowiczMakowska H, Dziki A, Ulanska J, Pander B, Blasiak J (2002) Antigen levels of the urokinase-type plasminogen activator and its gene polymorphisms in colorectal cancer. Cancer Lett 181: 23-30.

Rajaganeshan R, Prasad R, Guillou PJ, Chalmers CR, Scott N, Sarkar R, Poston G, Jayne DG (2007) The influence of invasive growth pattern and microvessel density on prognosis in colorectal cancer and colorectal liver metastases. Br J Cancer 96: 1112-1117.

Reijerkerk A, Mosnier LO, Kranenburg O, Bouma BN, Carmeliet P, Drixler T, Meijers JC, Voest EE, Gebbink MF (2003). Amyloid endostatin induces endothelial cell detachment by stimulation of the plasminogen activation system. Mol Cancer Res 1: 561-568.

Reuning K, Ulm H, Hofler F, Janicke H, Graeff AB (1997) Clinical impact of the plasminogen activation system in tumor invasion and metastasis: prognostic relevance and target for therapy. Thromb Haemost 78: 285-296.

Seetoo DQ, Crowe PJ, Russell PJ, Yang JL (2003) Quantitative expression of protein markers of plasminogen activation system in prognosis of colorectal cancer. J Surg Oncol 82: 184-193.

Shpitz B, Gochberg S, Neufeld D, Grankin M, Buklan G, Klein E, Bernheim J (2003) Angiogenic switch in earliest stages of human colonic tumorigenesis. Anticancer Res 23: 5153-5157.

Sieczkiewicz GJ, Hussain M, Kohn EC (2002) Angiogenesis and metastasis. Cancer Treat Res 107: 353-381.

Smolarz B, Romanowicz-Makowska H, Kulig A (2003) Plasminogen activator inhibitor 1 (PAI-1) 1334G/A genetic polymorphism in colorectal cancer. Acta Biochim Polon 50: 489-495.

Wang Y, Jones CJ, Dang J, Liang X, Olsen JE, Doe WF (1994) Human urokinase receptor expression is inhibited by amiloride and induced by tumor necrosis factor and phorbol ester in colon cancer cells. FEBS Lett 353: 138-142.

Zheng H, Takahashi H, Murai Y, Cui Z, Nomoto K, Niwa H, Tsuneyama K, Takano Y (2006) Expressions of MMP-2, MMP-9 and VEGF are closely linked to growth, invasion, metastasis and angiogenesis of gastric carcinoma. Anticancer Res 26: 3579-3583. 